\title{
Non-Viral Gene Therapy Vectors Carrying Genomic Constructs
}

\author{
George Kotzamanis, Hassan Abdulrazzak, \\ Athanassios Kotsinas and Vassilis G. Gorgoulis \\ University of Athens, Medical School
}

Greece

\section{Introduction}

Gene therapy is the use of genes or DNA for the treatment of diseases. For the treatment of inherited disorders, DNA carrying a functional gene is introduced into the cells of a patient to reverse the defect of the corresponding malfunctioning endogenous gene. Previous genetic characterization of the disease and cloning of the gene that causes it are necessary. In most cases, the cDNA of the therapeutic gene is cloned into a bacterial plasmid under the control of a strong heterologous promoter (often of viral origin). However, such constructs, called mini-genes, lack introns, promoters, enhancers, and long-range controlling elements that precisely control the temporal and spatial expression of the endogenous gene.

For gene therapy of some diseases it is important to achieve expression of the therapeutic gene at specific levels. Expression at lower levels than normal might not be sufficient to correct the defect and at higher levels could result in undesirable effects. In other cases, tissue-specific expression may be very important. The elements responsible for controlled and tissue-specific expression of a gene usually lie within the introns and the sequences before and after the gene. Therefore, the use of genomic constructs which contain the introns and flanking DNA of the therapeutic gene is expected to be more effective than that of minigene constructs in gene therapy for certain genetic diseases where precise levels of the gene product are required (reviewed by (Pérez-Luz \& Díaz-Nido, 2010)). Bacterial Artificial Chromosomes (BACs), originating from the human genome project, contain genomic loci of approximately $180 \mathrm{~kb}$ on average and cover the entire human genome (Osoegawa et al., 2001). These sequenced BACs can accommodate most genes along with their regulatory elements and can serve as tools in gene therapy using genomic constructs.

Gene therapy as a modern therapeutic tool should provide a permanent cure to the patient by long-term maintenance and expression of the administered gene. This can be achieved either by integration of the transgene into the natural chromosomes or by other mechanisms for its replication and nuclear retention.

One of the most important aspects of gene therapy is the choice of the vector that will deliver and express the corrective gene in the appropriate cells. Current vectors fall into two categories: viral and non-viral. Apart from determining the method of delivery, the type of vector also determines the fate of the therapeutic gene within the cells. For instance, the vector may have the ability to remain extra-chromosomally. Non-viral artificial chromosome vectors and adeno-associated viral, adenoviral, Herpes viral and EBV vectors are all 
examples of this type. In contrast, retroviral and lentiviral vectors integrate into the host genome (reviewed by (Verma \& Weitzman, 2005)).

The majority of current gene therapy approaches are based on viral vectors due to their highly efficient delivery into cells. There are some examples of successful viral gene therapy clinical trials which had impressive clinical benefit for the patients (Cavazzana-Calvo et al., 2000). However, viral gene therapy has been subjected to criticism mostly because of two unfortunate events. In one case a patient with ornithine transcarbamylase deficiency treated with an adenoviral vector died due to provocation of an immune response (Raper et al., 2003). This death raised a safety issue that is hard to address, as human immune responses cannot be predicted pre-clinically. In another case, SCID-X1 patients treated with a retroviral vector developed a leukemia-like condition due to disruption of an endogenous oncogene by integration of the vector (Hacein-Bey-Abina et al., 2003a, 2003b). Since vector integration is random and uncontrollable, insertional mutagenesis is a general problem that all integrating viral vectors have.

Ideally, vectors suitable for gene therapy should meet four criteria. Firstly, they should be safe. In this context all vectors that arise from non-human sequences might cause adverse immune responses and are not suitable. Additionally, vectors that integrate into the host genome at random positions are also unsafe. Secondly, they could be efficiently delivered into cells. Viral vectors have an advantage in this respect but recently developed physical methods for non-viral DNA delivery (Reviewed by (Al-Dosari \& Gao, 2009)) might prove to be equally effective. Thirdly, they should remain permanently in the cells and provide longterm expression of the transgene they carry. As random integration is excluded due to the first criterion, extra-chromosomally retained or site-specific integrating vectors might be an alternative solution. Fourthly, their cloning capacity should be high enough to allow them to carry fully functional genes with appropriate regulatory elements. Such intact genes, or gene clusters, can be very large and conventional molecular biology techniques will be inadequate for manipulating them. New technologies are therefore needed.

This chapter will focus on non-viral vectors containing entire genomic loci rather than minigenes. The necessity for using these constructs will become clear through several examples of preclinical work with integrating vectors conferring position independent expression from large transgenes. Key points on delivery of large naked DNA molecules into patients using physical methods will be covered. Emphasis will be given to ex vivo transfer of genomic constructs to cultured mammalian cells and nucleofection and bactofection as two promising methods for delivering large constructs will be analyzed. A review of all available vectors that allow extra-chromosomal maintenance of foreign DNA will be provided with an emphasis on the structure and potential application of EBV-based episomes, Human Artificial Chromosomes and Scaffod/Matrix Attachment Region (S/MAR) vectors as examples of non-integrating extra-chromosomally retained vectors. In addition, two systems for targeted integration at specific sites not associated with carcinogenesis will be described. The availability of powerful recombination-based methods for manipulating large vectors, a process called recombineering, will also be covered. Finally, an example on the development of genomic DNA containing vectors for gene therapy of Cystic Fibrosis using recombineering will be given.

\section{Advantages of use of genomic constructs in gene therapy}

The argument for using genomic constructs rather than cDNA in gene therapy is that they contain all the introns and flanking DNA which can confer full control of gene expression. 
Inclusion of introns also allows correct function of genes that encode for different products through differential splicing, such as the immunoglobulin genes. Promoters that lie in the flanking DNA could be cloned and used in a cDNA construct. However, the introns and flanking DNA also contain other elements that can participate in the control of chromatin condensation and therefore influence gene expression. The most important of these elements are simple enhancers and locus control regions (LCRs) (Lipps et al., 2003).

Enhancers increase transcription independently of orientation and distance. They can suppress silencing of transgenes that is usually observed when integration occurs in a condensed and therefore repressive heterochromatin region, a phenomenon called position effect (Martin \& Whitelaw, 1996). Moreover, they can target transgenes to transcriptionally active nuclear compartments and prevent their localization near heterochromatin (Francastel, et al., 1999). LCRs are more complex and contain enhancers (Li et al., 1999). A general characteristic they have is the presence of DNAse I hypersensitive sites (DHS), where chromatin is not condensed and transcription factors can bind to their cognate sequences allowing transgene expression.

The importance of using genomic constructs rather than cDNA or mini-genes has been shown for several genes, both in cultured cells and in transgenic mice. Generally, the presence of promoters, enhancers, LCRs and other elements, located $5^{\prime}$ or $3^{\prime}$ of the gene or within introns, resulted in position-independent expression of the transgenes in the correct tissue, at proper levels and right times in contrast to the use of small transgenes carrying heterologous promoters. For example transgenic mice generated with long constructs that included all the known DHS 5' of the class II MHC Ea gene showed position-independent, copy number dependent expression of $E a$. Shorter constructs lacking some of the DHS were subject to position effects (Carson \& Wiles, 1993). Similar results were obtained when a 250$\mathrm{kb}$ YAC carrying the genomic locus of the mouse tyrosinase gene was used to generate transgenic mice. The transgene was expressed at levels comparable to the endogenous gene, in the right tissues and proportional to copy number but independent of position (Schedl et al., 1993). Physiological expression of the human Huntington Disease gene has also been achieved from a YAC in transgenic mice containing a targeted disruption of the endogenous gene. Huntigtin is essential for development since its absence is lethal in mice but the human transgene was expressed in the correct tissue, at adequate levels and early enough in development to rescue the mice from embryonic lethality (Hodgson et al., 1996). Likewise, the human Friedrich ataxia (FRDA) gene expressed from a 188-kb BAC has been shown to rescue FRDA knockout mice from embryonic lethality (Sarsero et al., 2004). Transgenic mice were also generated with constructs covering the human $\beta$-globin locus, which is a model system for studying developmental regulation of gene clusters. The locus consists of five genes, $\varepsilon, G \gamma, A \gamma, \delta$ and $\beta$, the expression of which is tightly regulated both temporally and spatially. $\varepsilon$-globin is expressed at embryonic stages, $\mathrm{G} \gamma$ - and $\mathrm{A} \gamma$ - in the fetal liver and $\delta$ - and $\beta$-globin in the bone marrow of adults. An upstream LCR and a downstream DHS seem to control the expression of the genes. Transgenic mice generated by using a 160-kb BAC containing the entire human $\beta$-globin locus, exhibited proper developmental regulation and tissue specific expression of the globin genes (Huang et al., 2000). Interestingly, expression of a human BCL2L10 (Boo) BAC transgene targeted at the HPRT locus in transgenic mice, followed the human pattern. Human Boo mRNA was detected in organs that had no murine Boo mRNA but were known to host Boo expression in humans, suggesting that human regulatory elements which were present in the BAC and absent in the mouse endogenous gene could drive tissue-specific expression in the mouse background (Heaney et al., 2004). 
Transgenic work has also been carried out with respect to cystic fibrosis (CF). The disease is caused by mutations in the cystic fibrosis transmembrane conductance regulator (CFTR) which is normally expressed in specific tissues and shows precisely regulated expression thanks to some DHS that are found as far as $80 \mathrm{~kb}$ upstream of the first exon (Smith, et al., 1995). Previous experiments with small mini-gene constructs that obviously could not cover the whole genomic region showed some expression of CFTR in transgenic mice (Alton et al., 1993; Hyde et al., 1993) and low levels of transient correction in CF patients (Caplen et al., 1995). However, such constructs were not expressed sufficiently in the appropriate tissues to achieve clinical improvement in patients. A 320-kb YAC carrying the human CFTR gene rescued CFTR null mice (Manson et al., 1997). Gene expression followed the wild type mouse pattern except in some tissues such as the pyloric glands, Brunner's glands, epididymis and sublingual glands, presumably due to absence of a distant DHS in the YAC or lack of recognition of the human control elements by mouse transcription factors. More recently, correct temporal and spatial expression of the human COL6A1 gene (Xing et al., 2007), the human Brain-Derived neurotropic factor (BDNF) gene (Koppel et al., 2009) and the porcine Growth Hormone gene (Tong et al., 2010) has been demonstrated in BAC transgenic mice.

The ability of genomic constructs to drive tissue- and time-specific expression, unlike cDNA and mini-genes, has made BAC transgenics an additional tool to knockout transgenics for the identification of potential regulatory elements within the locus of a gene. For instance, an enhancer within the locus of the tyrosinase-related family (Tyrp1) gene (Murisier et al., 2006) and a region responsible for tissue-specific expression within the locus of the Neurogenin1 gene (Quiñones et al., 2010) have been discovered in transgenic mice generated with BACs.

\section{Delivery of large DNA molecules}

Gene therapy with large genomic constructs cloned on BAC vectors unavoidably raises the issue of delivery into target cells. The majority of recombinant viruses, commonly utilized as carriers for transfer of plasmid DNA, apart from evoking unwanted immune responses, have a maximum packaging capacity and cannot be used to deliver large BACs. An exception to this rule is the Herpes simplex virus 1 (HSV-1) -derived amplicon vector, which has been shown to be able to accommodate and deliver large BACs of up to approximately $150 \mathrm{~kb}$ in size (Wade-Martins et al., 2003). However, even this promising vector is based on viral sequences and is subject to criticism regarding its safety. Therefore, delivery of genomic loci of therapeutic genes should preferably be non-viral.

Irrespective of their size, naked DNA molecules are difficult to transfect into cells both in vivo and in vitro due to a series of barriers related to almost all aspects of cellular biology. Such barriers include degradation by nucleases present in the blood and the extracellular matrix, the plasma membrane, transformation of endosomes to digestive lysozomes following endocytosis and the nuclear envelope (Al-Dosari \& Gao, 2009). Several physical methods have been employed to facilitate transfer of naked DNA into cells with efficiencies that in some cases resemble those of viral methods. In parallel, chemical methods based mostly on cationic lipids and polymers have been developed and used for in vitro and in vivo gene transfer. However, the vast majority of published data concern delivery of plasmid DNA and further evaluation of both physical and chemical methods for the delivery of large BACs is required. 


\subsection{Physical methods for direct delivery to patients}

Physical methods facilitate entry of naked DNA into the cells by creating temporary microdisruption of the cell membrane due to physical forces, such as hydrostatic pressure, electric pulse, ultrasound, laser irradiation, magnetic fields and particle bombardment. As of March 2011, naked plasmid DNA has been used in 18.7\% ( $n=319)$ of clinical gene therapy trials (http://www.wiley.com/legacy/wileychi/genmed/clinical/).

\subsubsection{Injection}

In early experiments, naked plasmid DNA (or RNA) was injected directly into different organs of different animals and expression of reporter genes was detected at the sites of injection. In mice, this method was used to deliver and express reporter genes in several organs including skeletal muscle (Wolff et al., 1990) and lung (Meyer et al., 1995). Subsequently, expression of therapeutic genes has been achieved using this method and some human clinical trials for limb ischemia (Morishita et al., 2010), erectile dysfunction (Melman et al., 2007), Duchenne/Becker muscular dystrophy (Romero et al., 2004)) have been based on naked DNA injection into tissues. Although these were phase I or IIa trials aiming mostly at assessing safety, some transgene expression and clinical improvement has been shown but the level of expression was low.

A non-invasive alternative to conventional needle injection is jet injection. This technology is based on a high velocity narrow jet of liquid containing the DNA, which is able to penetrate the skin and underlying tissues. It is powered by compressed air and penetration in a specific tissue can be controlled by adjusting the air pressure. So far, the major application of jet injection has been the development of DNA vaccines (Raviprakash \& Porter, 2006). Thanks to technical improvements, the efficiency of delivery by jet injection has reached that of other non-viral methods and has been evaluated recently in a clinical trial on patients with melanoma and breast cancer (Walther et al., 2008).

Further progress in the field has led to the development of the so-called hydrodynamic injection, which is considered to be the most efficient non-viral gene delivery method in mice (Al-Dosari \& Gao, 2009). According to the hydrodynamic method, a high volume saline solution of plasmid DNA is injected into the tail vein at high velocity. Initial studies have shown that this results in high levels of gene expression in the liver (Liu, et al., 1999; Zhang et al., 1999). The hydrodynamic injection into the tail vain has also been shown to work relatively well with large BAC DNA (Hibbitt et al., 2007; Magin-Lachmann et al., 2004). Moreover, local hydrodynamic delivery into rabbit liver using catheter-assisted perfusion (Eastman et al., 2002) and pressure-mediated delivery to rat kidney (Maruyama et al., 2002) and to limb muscle of mammals (Hagstrom et al., 2004) have been achieved. it remains to be seen whether similar hydrodynamic methods could be deployed in human patients.

\subsubsection{Electroporation}

In vivo electroporation is the application of electrical pulses following local injection of DNA in the target tissue. This temporarily increases the cell membrane permeability and facilitates DNA uptake by a mechanism that remains unclear. Under optimal conditions the efficiency of plasmid DNA delivery by in vivo electroporation can approach that of viral methods but the efficiency decreases when larger DNA molecules are used. By using a variety of electrodes, ranging from needle to surface electrodes, electroporation has been shown to be effective at 
delivering small in size DNA to several tissues including muscle and lung (Brown et al., 2008; Dean et al., 2003). On the other hand, only few data is available about in vivo electroporation of large DNA molecules. In one study, efficient delivery of an 80-kb BAC into electroporated muscle has been achieved but, as expected, reporter gene expression from the BAC was found 5 -fold less efficient than from a plasmid (Magin-Lachmann et al., 2004). Increasing knowledge and technological progress in electroporation has resulted in its clinical application in humans for the treatment of melanoma (Daud et al., 2008) and in several ongoing clinical trials for the treatment of other cancers and for DNA vaccination.

\subsubsection{Sonoporation}

Sonoporation is a technique that uses ultrasound waves of high intensity and low frequency to cause the same effect on the plasma membrane as electroporation that is transient permeabilization in order to facilitate the delivery of DNA into cells. The mechanism is different to electroporation though. Ultrasound is believed to result in acoustic cavitation that can disrupt temporarily the cell membrane. When it is used in combination with microbubbles, which are gas-filled vesicles coated with albumin, polymers or phospholipids, cavitation and therefore local DNA uptake are enhanced (Wells, 2004). Such microbubbles are commercially available and their stability has been shown to affect directly the efficiency of in vivo sonoporation (Alter et al., 2009).

Several studies have shown in vivo delivery of plasmids carrying either reporter or therapeutic genes to different tissues including lung, heart and muscle (Xenariou et al., 2010; Alter et al., 2009; Sheyn et al., 2008) but comparative data, wherever provided, confirmed that the efficiency of sonoporation was significantly lower than that of electroporation. However, sonoporation is still being considered for clinical application in humans due to its non-invasive nature and lesser tissue damage caused compared to electroporation. Interestingly, a combination of electric pulses and ultrasound waves (electrosonoporation) for gene transfer into the skeletal muscle of mice showed 8-fold and 1.6-fold higher gene expression compared with electroporation and sonoporation alone, respectively (Yamashita et al., 2002).

\subsubsection{Other physical methods}

Particle bombardment via a gene gun, originally designed for DNA delivery in plants, is a non-viral gene transfer method based on gold particles coated with DNA. The particles are accelerated by pressurized gas and expelled onto tissues. This technique, also referred to as ballistic DNA delivery, has been used to deliver transgenes to skin, liver and muscle tissues of rats and mice (Yang et al., 1990) and DNA vaccines to skin, muscles and tumours in animal models and in human clinical trials. Recently, is has been shown to be efficient at delivering a small reporter gene to mouse liver in vivo (Chang et al., 2008). Almost no data is available on the ability of gene gun to deliver large DNA constructs in vivo. In just one study, a DNA vaccine containing a 183-kb BAC has been delivered using gene gun and has been shown to confer immune protection to chickens (Tischer et al., 2002).

A new promising method of gene transfer based on the utilization of infrared laser beam has been developed and used to deliver a small transgene to mouse muscle in vivo (Zeira et al., 2003). This study reported efficiency of delivery, assessed by measuring the intensity and duration of transgene expression, equal to that by electroporation but with less damage caused to the tissue. 
Finally, magnetic fields have been used to enhance in vivo targeted gene delivery. In this method, called magnetofection, the DNA is reversibly coupled to superparamagnetic nanoparticles which are directed to the target site, following local injection, via a highenergy magnetic field. In vivo magnetofection has been shown to work for small in size plasmid DNA delivery to the gastrointestinal tract of rats and the blood vessels of the ear of pigs (Scherer et al., 2002) and the respiratory epithelium of mice (Xenariou et al., 2006).

\subsection{Chemical methods for direct delivery to patients}

Chemical vectors used for gene delivery present a broad diversity, with hundreds of different reagents being available (Al-Dosari \& Gao, 2009), but generally fall into two main categories: cationic lipids and cationic polymers. These act by forming complexes with the negatively charged DNA, named lipoplexes and polyplexes respectively, which protect the DNA from nucleases and allow its entry into the cells by endocytosis, pinocytarosis or phagocytosis and its transfer into the nucleus by escaping of the complexes from the endosomes following their internalization. The mechanism by which these processes take place are different for lipoplexes and polyplexes and the overall efficiency depends on the chemical structure of the cationic lipids/polymers, the charge ratio between the cationic lipids/polymers and the DNA, the size and structure of the lipoplexes/polyplexes and the inclusion of helper lipids such as DOPE and cholesterol in the complexes (Tros de Ilarduya et al., 2010).

Over the years many cationic lipids showing high transfection efficiency were developed and lipofection has become the most common method for gene transfer in vitro. Unfortunately, lipoplexes are not equally good for in vivo delivery as most of them are inactivated after interaction with factors present in the blood. However, successful in vivo DNA delivery has been reported both with systemic and local administration. A single intravenous injection of lipoplexes into mice has been shown to result in reporter transgene expression in the lung, heart, liver, spleen, and kidney (Song et al., 1997). Impressively, local administration of cationic lipid/CFTR-plasmid-DNA complexes in an aerosol formulation to the lungs of cystic fibrosis transgenic mice resulted in correction of the ion transport defect (Hyde et al., 1993). Similar studies in human patients demonstrated some transgene expression but not at sufficient levels to provide a clinical benefit (Griesenbach and Alton, 2009).

Apparently, the choice of the cationic lipid to be used depends on the application and careful optimization of the transfection protocol is required considering that lipoplexes can also induce unwanted immune responses. Lipofection has been used in $6.4 \%(n=109)$ of gene therapy clinical trials (http://www.wiley.com/legacy/wileychi/genmed/clinical/).

There has also been an extensive use of cationic polymers in DNA delivery studies with polyethylenimine (PEI) being the most active reagent. Polyplexes are more stable than lipoplexes and their toxicity and transfection activity depend on their molecular weigh (mw). Polymers with low mw are more efficient and less toxic than those with high mw (Fischer et al., 1999). Interestingly, intravenous injection of PEI/BAC-DNA complexes in mice has been found to be less efficient than other non-viral gene delivery methods such as electroporation and hydrodynamic injection (Magin-Lachmann et al., 2004).

\subsection{Ex vivo delivery to cells}

An alternative to in vivo delivery of DNA for gene therapy is the ex vivo approach. This procedure consists of surgically removing target cells from a patient, transducing them with 
an appropriate therapeutic gene in culture and then reimplanting them into the body of the donor. Since it involves the use of autologous cells, there is no need for immunosupression following transplantation of the cells back to the patient. In most ex vivo gene therapy applications, transplanted cells need to integrate into the appropriate tissue and the efficiency of this "homing" process is tissue type-dependent.

Recent progress in stem cell research has revolutionized ex vivo therapy. Stem cells are characterized by their ability to differentiate into a diverse range of cell types when placed in the appropriate environment both in vitro and in vivo and can therefore be used directly in cell therapy (Abdulrazzak et al., 2010). An ex vivo cell therapy approach using Embryonic Stem Cells or foetal Mesenchymal Stem Cells would not involve transfection of a therapeutic gene and would overcome the low gene delivery efficiency hurdle. However, it would have to be used in an allogeneic fashion which would bring the need for using immunosuppressive drugs. A more attractive strategy would be the transfer of a therapeutic gene to patient-derived autologous stem cells such as Mesenchymal Stem Cells (MSCs) which can easily be isolated from the bone marrow or adipose tissue of adults and have been shown to have an excellent differentiation potential (Abdallah \& Kassem, 2008) or Induced Pluripotent Stem Cells that can be generated by reprogramming of adult somatic cells (Yu et al., 2007; Takahashi et al., 2007).

Several non-viral methods have been utilized to transfer DNA into MSCs for ex vivo gene therapy purposes. The aim of the following sections is to review two of them, nucleofection and bactofection. The criteria for this choice are their ability to deliver very large DNA molecules intact and/or maintain the differentiation potential of the MSCs following transfection.

\subsubsection{Nucleofection}

Nucleofector technology developed by Amaxa Biosystems is a non-viral method of gene transfer based on electroporation using a combination of electrical parameters and solutions that are specific for each cell type. Unlike other non-viral transfection methods, it facilitates the transfer of DNA directly into the cell nucleus. It is particularly useful for gene transfer into a variety of primary cell types from different species which are normally very difficult to transfect (Gresch et al., 2004).

Nucleofection has been shown to be able to efficiently deliver plasmid DNA carrying a reporter gene to MSCs without impairment of their differentiation capacity (Aluigi et al., 2006). Preliminary data on stable cell lines generated by nucleofection with large BACs suggest that nucleofection can also be used to deliver genomic constructs but does not result in all clones containing intact and unrearranged DNA (Cheung et. al., unpublished data).

\subsubsection{Bactofection}

Direct delivery of DNA into mammalian cells by invasive bacteria (bactofection) is another potentially useful technique for gene transfer and it may have applications for both in vitro and in vivo delivery (Larsen et al., 2008). In this method, the DNA is first introduced either in the form of a plasmid or a BAC into bacteria having the ability to invade eukayotic cells and subsequently these bacteria are used to invade and deliver their DNA content into target cells. Several bacterial systems allowing eukaryotic cell invasion have been described. The most convenient is based on the the E. coli strain BM4573 (Laner et al., 2005). BM4573 bacteria have been modified to 1) stably express 
invasin, from the inv gene of Yersinia pseudotuberculosis, which binds to $\beta 1$-integrins on mammalian cells leading to internalization, 2) have permanent impaired cell wall synthesis due to diaminopimelic acid (DAP) auxotrophy which causes bacterial lysis following internalization and 3) stably express listeriolysin $\mathrm{O}$, from the hly locus of Listeria monocytogenes, which is a pore-forming cytolysin that allows escape from the vacuole after bacterial entry and release of the DNA into the cytosol resulting in greater levels of transgene expression (Laner et al., 2005).

One advantage of the method is that there is no need to purify the DNA prior to transfection, which is still a technically challenging procedure for very large DNA molecules. Another advantage is that DNA delivered by bacterial invasion is rarely rearranged. Rearrangements are always an issue of concern when using other DNA delivery methods to transfer large BACs. For instance, although lipofection and electroporation have been used to efficiently deliver large BAC DNA into cultured cells, some of the clones generated have been shown to suffer from rearrangements (Magin-Lachmann et al., 2004; Cheung et al., unpublished data). In contrast, several studies have demonstrated that large BACs are delivered intact by bacterial invasion albeit with low efficiency. In two of them, stable cell lines containing integrations of a $\sim 250-\mathrm{kb}$ BAC carrying the human clotting factor VIII (FVIII) gene (Pérez-Luz et al., 2007) and of a $\sim 258-\mathrm{kb}$ BAC carrying the human CFTR gene (Kotzamanis et al., 2009) have been generated by bacterial invasion. No clones have been found to contain rearranged DNA in any of the two studies and expression of the respective transgenes has also been shown in both of them. Therefore, bactofection is an attractive method for delivering large genomic DNA containing intact constructs. The ability of the method to deliver large BACs into MSCs without affecting their differentiation potential is yet to be shown.

\section{Extra-chromosomal vectors}

Regardless of the type and size of the therapeutic gene (small cDNA versus large genomic DNA) and the delivery method (viral versus non-viral) to be used in a gene therapy protocol, efficient retention and long-term expression of the transgene is required so as to eliminate the need for re-administrations. Integration into the host genome has widely been used in gene therapy to fulfil this requirement. However, the dangers of integration due to insertional mutagenesis have become a widely publicised issue as a result of a clinical trial using a retroviral vector to treat $\mathrm{X}$-linked severe combined immune deficiency (SCIDX1). In this trial some patients developed leukaemia due to deregulation of the growth-promoting LIM domain only 2 (LMO2) proto-oncogene caused by integration of the vector (HaceinBey-Abina et al., 2003a, 2003b). The safety concerns regarding uncontrolled integration of the therapeutic gene into the host genome have been strengthened by observations that there is a preference of integrating vectors for the regulatory regions of transcriptionally active genes (Bushman et al., 2005). Given the need for long-term expression and the problems associated with vector integration, vectors that persist in the nucleus by being maintained episomally without integrating could be highly advantageous. Three different systems have been employed to achieve extra-chromosomal maintenance of the vectors carrying the therapeutic gene: systems based on elements from the Epstein-Barr virus (EBV), artificial chromosomes and systems based on scaffold/matrix attachment region (S/MAR). All these systems have a high cloning capacity and can be used in combination with large genomic constructs. 


\subsection{OriP/EBNA-1 episomal vectors}

The best characterized system for episomal maintenance is based on sequences derived from the EBV genome. EBV is a member of the herpesvirus family with a 172-kb genome that is latently maintained as an independently replicating episome in a small percentage of infected lymphocytes (Masucci \& Ernberg, 1994). During the latent phase of its cycle, DNA replication occurs from the origin of replication oriP and only about 10 proteins are produced of which the only protein that is required for replication at oriP is the Epstein Barr Nuclear Antigen-1 (EBNA-1) (Yates et al., 1985). The interaction of oriP with EBNA-1 also enables the segregation of the viral genome between the daughter cells through the association of EBNA-1 with host metaphase chromosomes (Harris et al., 1985).

These features of the EBV have been exploited to develop a system for episomal maintenance of foreign DNA delivered into cells. It has been shown that plasmids carrying oriP and expressing EBNA-1 can replicate autonomously once per cell cycle when delivered into human cells and can segregate by attaching to the host chromosomes (Haase \& Calos, 1991). The oriP/EBNA-1 system has also been shown to support long-term episomal maintenance without selection and expression of very large human genes, such as the CFTR (Huertas et al., 2000), the human hypoxanthine phosphoribosyltransferase (HPRT) (WadeMartins et al., 2000) and the $\beta$-globin gene (Black \& Vos, 2002). Following these promising results, a convenient system for adding the oriP/EBNA-1 sequences onto any BAC already containing a therapeutic gene has been developed (Magin-Lachmann et al., 2003) and will be analyzed later on.

The oriP/EBNA-1 retention system is easy to use and can provide extra-chromosomal maintenance to foreign DNA of hundred kilobases delivered into cells but has some major disadvantages. It provides random rather than equal segregation of the episomal vector to daughter cells which results in loss of the episomes at a rate of 2-8\% per cell division (Sclimenti \& Calos, 1998). This, along with the fact that it involves viral sequences particularly from the EBV which has been associated to several types of human malignancies (Cohen, 2000) limits the use of EBV vectors for safe gene therapy.

\subsection{Human artificial chromosomes}

Human Artificial Chromosomes (HACs) are vectors able to replicate and segregate in parallel with the endogenous chromosomes in human cells. To achieve this, they must contain the minimal elements required for chromosome function, namely an origin of replication, telomeres and centromeres (Pérez-Luz \& Díaz-Nido, 2010).

One approach towards constructing HACs, called "top-down", involves fragmentation of already existing chromosomes and generation of smaller mini-chromosomes, where only the three functional chromosomal elements remain. Several studies have shown that minichromosomes can host and allow the expression of large therapeutic genes, be transferred between various mouse and human cell lines and be transmitted through the mouse germ line (Kakeda et al., 2005; Shen et al., 2001; Voet et al., 2001). Though mini-chromosomes have useful properties for application in transgenics, their use in gene therapy is restricted to an ex vivo approach only.

HACs with a high potential for use in in vivo gene therapy are generated by a different approach named the bottom-up. This is similar to the method applied for YAC construction in yeast and involves assembling the functional chromosomal elements and building up a HAC de novo in human cells. Different strategies have been followed to generate de novo HACs, the most convenient of which is to transfect a BAC carrying only a large array of $\alpha$ - 
satellite (alphoid) DNA and some marker genes into HT1080 cells. No telomeric sequences or an origin of replication have been shown to be required, probably due to generation of circular HACs and initiation of replication at origins found within the marker genes (Ebersole et al., 2000). HACs generated this way exist as single (or low copy) chromosomes in the nucleus and have a high mitotic stability (close to 100\%) in the absence of selection. The potential use of these vectors in gene therapy has been demonstrated by expression of large therapeutic genes from them (Grimes et al., 2001; Mejía \& Larin, 2000). Further advance was noted when efficient methods for manipulating large sequences of repetitive nature, such as alphoid DNA, were developed and used to generate HACs, as will be discussed later on (Kotzamanis et al., 2005). Nevertheless, several issues need to be solved before any clinical application. First, HACs have been shown to form efficiently only in HT1080 cells so far. Whether this is due to their inability to form in other cell lines has not been answered yet, but is limiting their use for in vivo gene therapy. Second, all HACs produced by de novo synthesis in HT1080 cells have been between 1 and $10 \mathrm{Mb}$ in size, definitely smaller than native chromosomes, but larger than the input DNA, suggesting that unpredictable amplifications and rearrangements have occurred during their formation, which is not desired for safe gene therapy vectors. Third, other fates of the input DNA than formation of HACs have been observed and integration has not been excluded (Harrington et al., 1997). This would not be a problem in ex vivo therapy where individual clones expressing the gene of interest from a HAC could be isolated, but in in vivo gene therapy, any interaction of the input DNA with the endogenous chromosomes could have the same consequences as viral vectors have. Further research is necessary to increase the efficiency of $\mathrm{HAC}$ formation so as to ensure that no integration events take place.

\subsection{S/MAR vectors}

S/MARs are diverse sequences found in all eukaryotic genomes where they are involved in many aspects of chromatin function such as organization of chromatin into loops, which seems to be mediated by the interaction between $S / M A R s$ and the nuclear matrix (Heng et al., 2004). Experiments with a plasmid vector containing an $S / M A R$ element isolated from the human interferon $\beta$ - gene has revealed one more feature of $S / M A R s$, their ability to provide episomal maintenance of foreign DNA introduced into cells. This vector was able to replicate and remain episomally in $\mathrm{CHO}$ cells at low copy number for more than 100 generations in the absence of selection and with a mitotic stability of $98 \%$ (Piechaczek et al., 1999). It was later confirmed that the mitotic stability of the vector was provided through the interaction of the $S / M A R$ with the nuclear matrix (Baiker et al., 2000). Interestingly, the $S / M A R$ used seemed to prevent vectors from integrating into the host genome as integration events were observed in less than $1 \%$ of stably transfected clones (Jackson et al., 2006). The ability of the interferon $\beta S / M A R$ to provide replication and episomal retention has been demonstrated in several cell lines and in primary cells (Papapetrou et al., 2006) and also in vivo in genetically modified pigs (Manzini et al., 2006). Furthermore, the same S/MAR element has been introduced by site-specific homologous recombination to a BAC carrying $135 \mathrm{~kb}$ of the human low density lipoprotein receptor (LDLR) genomic locus and shown to provide low copy episomal maintenance in $\mathrm{CHO} l d l r /$ - cells for more than 100 generations without selection and long-term expression of the transgene at high enough levels to completely restore LDLR function in these cells (Lufino et al., 2007).

In summary, it seems that unlike viral episomal vectors which need to encode viral factors required for their function, S/MAR vectors achieve their replication and segregation by 
recruiting and interacting with host cell proteins. Moreover, unlike HAC vectors, S/MAR vectors do not need to undergo amplifications and rearrangements to function and are therefore of defined structure and composition. These unique safety properties of S/MARS make them very attractive for use in gene therapy with large genomic constructs.

\section{Vectors integrating at specific sites}

An alternative to the use of episomal vectors described above, that still satisfies both requirements for permanent transgene expression and elimination of genotoxic effects is the controlled integration of the therapeutic construct at a specific site in the host genome where no active genes are present. Several vector systems have been developed to achieve this, with each one of them having its own limitations (Voigt et al., 2008). From this variety of available vectors, only two types will be described based on their preference for specific sequences that already exist in the human genome, their potential for in vivo use and their ability to support integration of large genomic constructs.

\subsection{Phage integrase based vectors}

The Streptomyces phage $\Phi C 31$ integrase is an enzyme that can catalyze site-specific recombination between a phage attachment site $(a t t P)$ and a bacterial attachment site $(a t t B)$ resulting in integration of $\Phi C 31$ into the bacterial genome and initiation of the lysogenic phase of its life cycle (Groth \& Calos, 2004). This integrase has been shown to be able to irreversibly integrate a single copy of foreign DNA, containing the attP site, into the human genome at native pseudo att sites found in the intergenic regions on human chromosomes and far from known oncogenes (Chalberg et al., 2005).

A series of studies have validated the potential of $\Phi C 31$ integrase-based vector systems in $e x$ vivo gene therapy by demonstrating expression of different therapeutic genes in cultured cells including human embryonic stem cells (Thyagarajan et al., 2008) and in in vivo gene therapy by showing expression of different therapeutic genes in animal models, like the dystrophin gene in dystrophic mouse muscle (Bertoni et al., 2006). Evidence that the system can be used in gene therapy with genomic constructs has been provided by transgenic work in Drosophila, where the $\Phi C 31$ integrase has been used to integrate large DNA fragments of up to $133 \mathrm{~kb}$ into the genome (Venken et al., 2006). However, other studies have questioned the safety of such vectors by showing that stably expressed ФC 31 integrase could cause numerous chromosomal abnormalities in human cells (Liu et al., 2006) and that in some cases $\Phi C 31$-mediated integration is associated with chromosome rearrangements, probably due to recombination between cryptic att sites (Ehrhardt et al., 2006). Recently developed mutational derivatives of $\Phi C 31$ integrase that have higher integration efficiency and specificity, may eliminate the safety concerns for its use in gene therapy (Keravala et al., 2009).

A very similar approach for site-specific integration is based on the utilization of transposase enzymes, with the Sleeping beauty and the piggyBac being the most thoroughly studied, which allow for the integration of foreign genes into genomic regions containing transposable elements. (Ivics \& Izsvak, 2010). However, such systems are unlikely to prove useful for integration of large genomic constructs as their ability to transpose is significantly decreased when the insert length is increased, a phenomenon called "length-dependence" (Atkinson \& Chalmers, 2010). 


\subsection{Adeno-associated virus based vectors}

Some features of the Adeno-associated virus (AAV) can be exploited for site-specific integration of foreign DNA. AAV is a non-pathogenic virus with a $4.7 \mathrm{~kb}$ single-stranded DNA genome comprising two genes, rep and cap flanked by 145 bp palindromic sequences termed inverted terminal repeats (ITRs) (Srivastava et al., 1983). In the presence of a helper virus such as adenovirus or herpes simplex virus, AAV can undergo replication and enter its lytic cycle while in their absence AAV integrates into the human genome and becomes latent. The ITRs contain the sequences required for replication, packaging and integration of the virus and the rep gene encodes four regulatory proteins required for catalysis of integration into the human genome during latency. Integration occurs into a specific site on chromosome 19 called the AAVS1 (Kotin et al., 1992).

It has been shown that human transgenes flanked by ITRs can integrate into the AAVS1, with the minimal requirement for expression of viral Rep in cultured human cells (Cortés et al., 2008), and in vivo in transgenic mice carrying the human AAVS1 (Liu et al., 2010; Recchia et al., 2004) . The AAV system has also been shown to be able to integrate large genes of $100 \mathrm{~kb}$ in size into the AAVS1 (Oehmig et al., 2007). These studies have demonstrated the effectiveness of AAV-based vectors but again safety issues have emerged. Integration of small transgenes has been detected in 10-30\% of infected human cells in culture with only about half of the integrations occurring specifically at the AAVS1 (Recchia \& Mavilio, 2006), suggesting that there would be a $50 \%$ probability of insertional mutagenesis in a gene therapy application. In addition, persistent expression of the viral Rep protein is toxic and can cause chromosome instability and mobilisation of the transgene (McCarty et al., 2004).

\section{Methods for modification of large DNA molecules}

Gene therapy using genomic constructs entails engineering of large DNA fragments often of repetitive nature. For instance, marker genes and other useful sequences, able to confer extra-chromosomal maintenance, need to be added to vectors carrying large genomic fragments, without causing any rearrangements. In other cases, the entire genomic locus of a therapeutic gene may not be available in a single BAC vector and linking of the inserts of two or more BACs is necessary. The technical difficulty in performing such manipulations has hampered progress in this field for a long time. Only recently, efficient engineering methods have been developed allowing the consideration of BACs carrying genomic loci as gene therapy vectors.

\subsection{Addition of marker and small genes}

In most cases, the cloning of mammalian selectable markers and small reporter genes on the vector region of a BAC carrying a genomic insert by classic molecular biology procedures is limited by lack of convenient cloning sites on the vector, the possible presence of many restriction sites in the insert and the difficulty in manipulating large DNA molecules without affecting their integrity. Alternatives to classic molecular biology techniques using restriction enzymes are therefore required. For adding reporter genes and short sequences onto BACs, site specific homologous recombination mediated by the bacteriophage P1derived Cre/loxP system is such an alternative.

The Cre protein recognizes and catalyses efficiently recombination only between specific lox $P$ sites, which are present on all BAC vectors making a modification method based on them 
generally applicable. As shown in Figure 1, the first step in such a method is the construction of a suitable retrofitting plasmid (pRetro) that carries the gene to be added onto the BAC, a loxP site and a selectable marker. Replication of pRetro depends on the high-copy gamma origin ( $\gamma$-ori) that only operates in an E. coli host expressing the $\pi$ protein (product of the pir gene). Following insertion of the plasmid into the BAC in the DH10B E. coli host which does not express $\pi$, the $\gamma$-ori becomes not functional and the BAC remains low-copy. The system shown in Figure 1 uses a separate plasmid to express Cre that is co-transfected with the retrofitting plasmid and then lost once retrofitting has occurred without being involved in the recombination process as it does not have a loxP site (Mejía \& Larin, 2000). This plasmid contains a LacZ-cre fusion gene so that Cre is expressed after IPTG induction and also a temperature sensitive origin of replication that is functional only at $30^{\circ} \mathrm{C}$. As shown in Figure 1 , in vivo retrofitting of the $\mathrm{BAC}$ with pRetro occurs at $30^{\circ} \mathrm{C}$ and then bacteria are grown at $42^{\circ} \mathrm{C}$ so that the Cre expressing plasmid is lost to avoid any further unwanted recombination events. Various pRetro plasmids for conveniently adding a G418 mammalian selectable marker, a GFP reporter gene, a luciferase reporter gene and/or an OriP/EBNA-1 element onto any BAC have been made available (Magin-Lachmann et al., 2003).

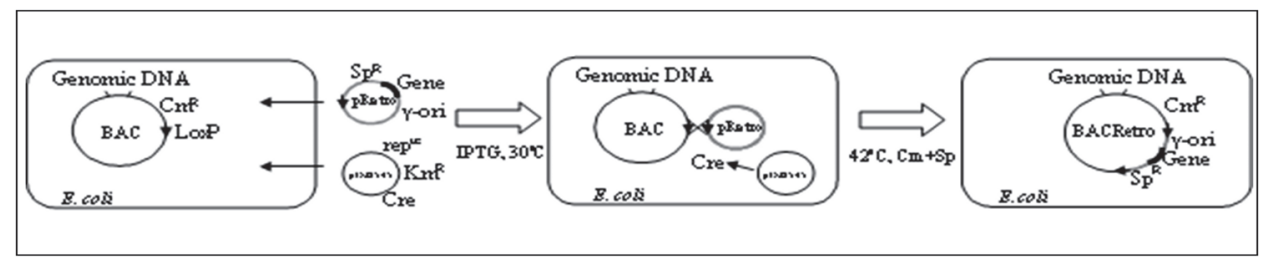

Fig. 1. Addition of small marked/reporter genes onto BACs by Cre/loxP recombination

\subsection{Addition of large sequences}

The construction of a genomic DNA-containing gene therapy vector with the ability to remain extra-chromosomally may involve the addition of large stretches of DNA that are difficult to clone into a pRetro plasmid in order to add them to a BAC by Cre/loxP recombination, as described in the previous section. For example, a 70-kb alphoid array has been shown to be required so as to enable a PAC vector to form HACs in HT1080 cells (Ebersole et al., 2000). For such applications, a method for manipulating large segments of DNA, based on homologous recombination in E. coli and termed recombineering, has been developed (Copeland et al., 2001). In recombineering, the sequence to be introduced is flanked by two regions of homology to the BAC, the length of which depends on the recombination system that catalyzes the recombination reaction. A selectable marker is also included in most applications so as to allow selection for correctly retrofitted clones in $E$. coli. The phage recombination systems RecET and Red consist of genes encoding proteins involved in homologous recombination of cryptic Rac prophage and bacteriophage $\lambda$ respectively. These systems are relatively efficient, do not require long homology regions and rarely catalyze unwanted recombination events when used in recombineering (Court et al., 2002; Muyrers et al., 2001). Particularly the Red recombination system has been used to introduce a 70-kb alphoid array into a BAC, carrying a 156-kb genomic insert containing the HPRT gene, by recombineering (Figure 2) and expression of the HPRT gene from generated HACs has been demonstrated (Kotzamanis et al., 2005). As shown in Figure 2, recombination was targeted to the chloramphenicol resistance gene which is present on all 
BACs, allowing for the addition of the 70-kb alphoid array into any BAC and subsequent formation of HACs in the appropriate cells (Kotzamanis et al., 2005).

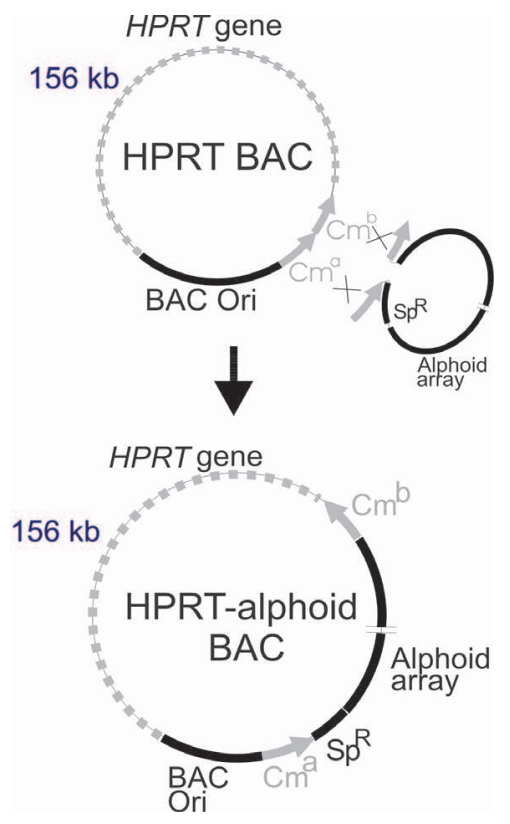

Fig. 2. Addition of large arrays of alphoid DNA onto BACs by recombineering

\subsection{Linking of two overlapping BACs}

There are many large human genes which are of the same order of size, or larger, than the average insert size of the BAC libraries and for these it is often difficult to find a single BAC spanning the entire gene with all its associated controlling elements. Gene therapy using the genomic loci of such genes would require the assembly of different sequences into a single BAC clone by linking together all available overlapping BAC clones spanning the desired region. Recombineering mediated by the Red system from the $\lambda$-prophage has been used to link two overlapping BACs (Kotzamanis \& Huxley, 2004; Zhang \& Huang, 2003) and linking has been shown to be precise without causing any rearrangements, including shifting of the reading frame of the therapeutic gene (Kotzamanis et al., 2009). As shown in Figure 3, the method comprises two rounds of homologous recombination to link the inserts of two overlapping BACs. In the first round, the inserts of the BACs are subcloned into modified BAC vectors ( $\mathrm{pBACLink}$ vectors linearized by NotI) by homologous recombination at regions indicated as Hom A, HomB and HomC (which are PCR amplified and cloned into the pBACLink vectors prior to their linearization). In the second round, one of the modified BACs is linearized by the rare cutting enzyme I-PpoI and introduced into recombination efficient bacteria containing the other modified BAC, resulting in recombination at HomB and $\mathrm{Cm}^{\mathrm{a}}$ (part of the chloramphenicol resistance gene present on all BACs) and linking of the two inserts in a single BAC. More overlapping BAC inserts can be added by alternating use of the two pBACLink vectors described in the study (Kotzamanis \& Huxley, 2004). 

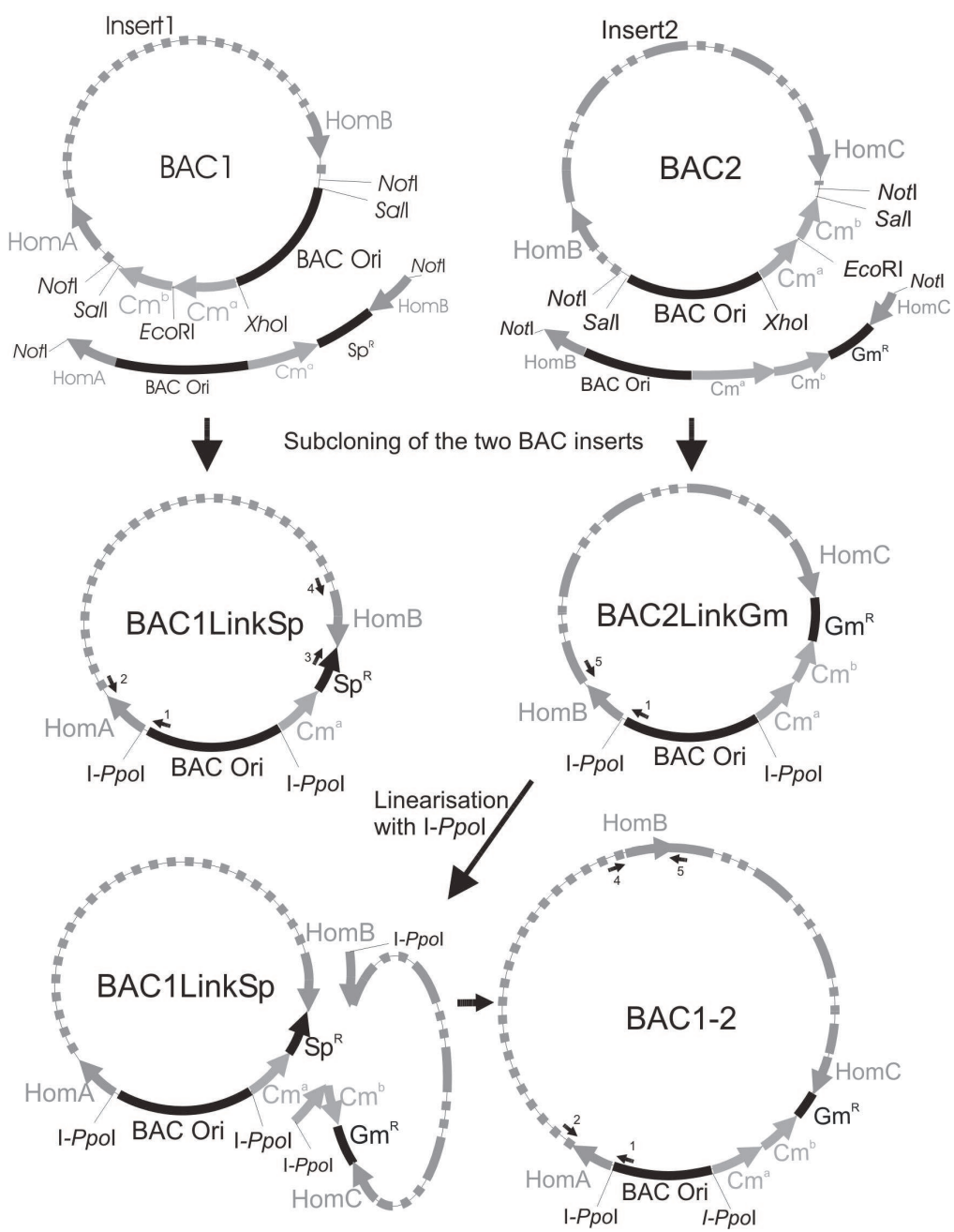

Fig. 3. Linking of two overlapping BACs into a single larger BAC

\section{Towards gene therapy of cystic fibrosis using a genomic construct}

Cystic Fibrosis is the most common genetic disease in the Caucasians caused by mutations in the CFTR gene which is $250 \mathrm{~kb}$ long and encodes a cAMP regulated transmembrane $\mathrm{Cl}-$ ion channel in epithelial cells of several organs. The most severe implications which eventually lead to death are in the lungs (Boucher, 2002).

For several reasons including the easy access to the respiratory tract without any intervention procedures, the cloning and the characterization of the CFTR gene (Riordan et al., 1989; Rommens et al., 1989) and the expectation that even relatively low levels of expression of the gene may have a therapeutic outcome (Dorin et al., 1996), Cystic Fibrosis became an ideal target for gene therapy. 
In previous preclinical and clinical studies where CFTR cDNA-heterologous promoter systems and different viral vectors were used for the delivery and expression of the transgene, some expression has been shown in transgenic mice and low levels of transient correction of $\mathrm{Cl}$ - ion transport deficiency has been observed in patients but no significant clinical improvement has been achieved (Griesenbach \& Alton, 2009).

Due to the strict regulation of expression of the CFTR gene at specific developmental stages and in specific tissues, controlled by regulatory elements found before, after and within the gene (McCarthy \& Harris, 2005), the use of constructs covering the whole genomic locus of the gene may have a better therapeutic potential for Cystic Fibrosis. To date, the only transgene that has fully restored transgenic mice, which did not express endogenous CFTR and would normally die, is the intact gene present on a YAC of approximately 300 $\mathrm{kb}$ in length (Manson et al., 1997). However, YAC vectors have the disadvantage of being difficult to shuttle between cells and are inherently unstable and therefore have been replaced by BACs. The CFTR gene is one of the large human genes that have not been found to be contained intact in any of the sequenced BACs available from the Human Genome Project. For this reason, the technology described in section 6.3 was developed and used to construct a BAC vector carrying the whole CFTR gene and the associated regulatory elements (Kotzamanis et al., 2009). Successful transcription of the gene to a correctly spliced mRNA has been demonstrated in a mouse cell line. This BAC is the only CFTR genomic system available on a convenient vector and may be the basis for non viral gene therapy for Cystic Fibrosis.

Viral approaches to gene therapy for Cystic Fibrosis suffer from gene delivery barriers such as absence of viral receptors in the respiratory epithelium and safety concerns such as provocation of an inflammatory response. This makes either in vivo or ex vivo non viral gene therapy an attractive avenue of research. However, several issues need to be solved before any clinical application. For instance, the in vivo delivery of non viral vectors is limited by the low efficiency, which becomes lower when bigger constructs are used. The demonstration that bone marrow-derived MSCs were able to differentiate to several types of cells including airway epithelial (Wang et al., 2005) indicated a potential application in an ex vivo approach but this is limited by poor data on how the ex vivo corrected MSCs can be administered and engrafted in the lung of Cystic Fibrosis patients.

Ideally, genetic manipulation with the CFTR BAC whether in the form of in vivo or ex vivo gene therapy would have to confer permanent transgene expression to avoid repeated gene or cell administration, respectively. In this regard, any of the systems that allow episomal maintenance or targeted integration at non-associated with carcinogenesis regions (described in sections 4 and 5) would have to be added to the CFTR BAC. The methodology required to add small sequences such as the OriP/EBNA-1 or the S/MAR elements, or large sequences such as the 70-kb alphoid array onto the CFTR BAC is available (see sections 6.1 and 6.2). Moreover, several methods for either in vivo or ex vivo delivery of the final construct to the respiratory epithelium have been developed and are available for use with the genomic CFTR-locus containing BAC (see section 3).

\section{Conclusion}

Non-viral gene therapy using the entire genomic locus of the therapeutic gene has two advantages over viral cDNA gene therapy; it is not associated with unwanted immune responses and can confer controlled levels of transgene expression in correct time and 
tissue. When combined with a system for extra-chromosomal maintenance or targeted integration it can provide permanent transgene expression without causing insertional mutagenesis and is therefore considered to be very safe. Among all available systems, the S/MAR element seems to be the most efficient, safe and convenient and may also be utilized in vivo. The problem of difficulty in manipulating large segments of DNA and in delivering them into cells in vitro or in vivo, which has been limiting the use of genomic constructs in gene therapy for years, has started finding its solution by the development of recombineering and of several physical and chemical methods for gene transfer. Apparently, there will not be a delivery system for general use and the choice of the most appropriate delivery method will depend on the specific application and gene therapy strategy.

\section{Acknowledgements}

This work was funded by the Greek Ministry of Development-GSRT (ENTER 04EP56), the Greek Ministry of Health-KESY (70/3/10295) and the University of Athens (Kapodistrias 70/4/9913).

\section{References}

Abdallah, BM. \& Kassem, M. (2008). Human mesenchymal stem cells: from basic biology to clinical applications. Gene therapy, 15(2), pp. 109-16.

Abdulrazzak, H., Moschidou, D., Jones, G. \& Guillot PV. (2010). Biological characteristics of stem cells from foetal, cord blood and extraembryonic tissues. Journal of Royal Society Interface, 6(7), pp. 689-706

Al-Dosari, MS. \& Gao, X. (2009). Nonviral gene delivery: principle, limitations, and recent progress. AAPS journal, 11(4), pp. 671-81.

Alter, J., Sennoga, CA., Lopes, DM., Eckersley, RJ. \& Wells, DJ. (2009). Microbubble stability is a major determinant of the efficiency of ultrasound and microbubble mediated in vivo gene transfer. Ultrasound in medicine $\mathcal{E}$ biology, 35(6), pp. 976-84.

Alton, EW, Middleton, PG., Caplen, NJ., Smith, SN., Steel, DM., Munkonge, FM., Jeffery, PK., Geddes, DM., Hart, SL. \& Williamson, R. (1993). Non-invasive liposomemediated gene delivery can correct the ion transport defect in cystic fibrosis mutant mice. Nature genetics, Vol. 5, pp. 135-42.

Aluigi, M., Fogli, M., Curti, A., Isidori, A., Gruppioni, E., Chiodoni, C., Colombo, MP., Versura, P., D’Errico-Grigioni, A., Ferri, E., Baccarani, M. \& Lemoli, RM. (2006). Nucleofection is an efficient nonviral transfection technique for human bone marrow-derived mesenchymal stem cells. Stem cells, 24(2), pp. 454-61.

Atkinson, H. \& Chalmers, R. (2010). Delivering the goods: viral and non-viral gene therapy systems and the inherent limits on cargo DNA and internal sequences. Genetica, 138, pp. 485-498

Baiker, A., Maercker, C., Piechaczek, C., Schmidt, S. B., Bode, J, Benham, C. \& Lipps, H. (2000). Mitotic stability of an episomal vector containing a human scaffold/matrixattached region is provided by association with nuclear matrix. Nature cell biology, 2(3), pp. 182-4.

Bertoni, C., Jarrahian, S., Wheeler, TM., Li, Y., Olivares, EC., Calos, MP. \& Rando, TA. (2006). Enhancement of plasmid-mediated gene therapy for muscular dystrophy by 
directed plasmid integration. Proceedings of the National Academy of Sciences USA, 103(2), pp. 419-24.

Black, J., \& Vos, JM. (2002). Establishment of an oriP/EBNA1-based episomal vector transcribing human genomic beta-globin in cultured murine fibroblasts. Gene therapy, 9(21), pp. 1447-54.

Boucher, RC. (2002). An overview of the pathogenesis of cystic fibrosis lung disease. Advanced drug delivery reviews, 54(11), pp. 1359-71.

Brown, PA., Khan, AS., \& Draghia-Akli, R. (2008). Delivery of DNA into skeletal muscle in large animals. Methods in molecular biology, 423, pp. 215-24.

Bushman, F., Lewinski, M., Ciuffi, A., Barr, S., Leipzig, J., Hannenhalli, S. \& Hoffmann, C. (2005). Genome-wide analysis of retroviral DNA integration. Nature reviews. Microbiology, 3(11), pp. 848-58.

Caplen, NJ., Alton, EW, Middleton, PG., Dorin, JR., Stevenson, BJ., Gao, X., Durham, SR., Jeffery, PK., Hodson, ME. \& Coutelle, C. (1995). Liposome-mediated CFTR gene transfer to the nasal epithelium of patients with cystic fibrosis. Nature medicine, 1(1), pp. 39-46.

Carson, S., \& Wiles, MV. (1993). Far upstream regions of class II MHC Ea are necessary for position-independent, copy-dependent expression of Ea transgene. Nucleic acids research, 21(9), pp. 2065-72.

Cavazzana-Calvo, M, Hacein-Bey, S., Saint Basile, G. de Gross, F., Yvon, E., Nusbaum, P., Seiz, F., Hue, C., Certain, S., Casanova, JL., Bousso, P., Deist, FL. \& Fischer, A. (2000). Gene therapy of human severe combined immunodeficiency (SCID)-X1 disease. Science, 288(5466), pp. 669-72.

Chang, M.L., Chen, JC., Yeh, CT., Chang, MY., Liang, CK., Chiu, CT., Lin, DY. \& Liaw, YF. (2008). Gene gun bombardment with DNA-coated gold particles is a potential alternative to hydrodynamics-based transfection for delivering genes into superficial hepatocytes. Human gene therapy, 19(4), pp. 391-5.

Cohen, JI. (2000). Epstein-Barr virus infection. New England journal of medicine, 343(7), pp. 481-92.

Copeland, NG, Jenkins, NA, \& Court, DL. (2001). Recombineering: a powerful new tool for mouse functional genomics. Nature reviews. Genetics, 2(10), pp. 769-79.

Cortés, ML, Oehmig, A., Saydam, O., Sanford, JD., Perry, KF, Fraefel, C. \& Breakefield, X. (2008). Targeted integration of functional human ATM cDNA into genome mediated by HSV/AAV hybrid amplicon vector. Molecular therapy, 16(1), pp. 81-8.

Court, DL., Sawitzke, JA., \& Thomason, LC. (2002). Genetic engineering using homologous recombination. Annual review of genetics, 36, pp. 361-88.

Daud, AI., DeConti, RC., Andrews, S., Urbas, P., Riker, A. I., Sondak, V. K., Munster, P., Sullivan, D., Urgen, K., Messina, J. \& Heller, R. (2008). Phase I trial of interleukin-12 plasmid electroporation in patients with metastatic melanoma. Journal of clinical oncology, 26(36), pp. 5896-903.

Dean, DA., Machado-Aranda, D., Blair-Parks, K., Yeldandi, AV., \& Young, JL. (2003). Electroporation as a method for high-level nonviral gene transfer to the lung. Gene therapy, 10(18), pp. 1608-15.

Dorin, JR., Farley, R, Webb, S., Smith, SN., Farini, E., Delaney, SJ., Wainwright, B., Alton, EW. \& Porteous, DJ. (1996). A demonstration using mouse models that successful 
gene therapy for cystic fibrosis requires only partial gene correction. Gene therapy, 3(9), pp. 797-801.

Eastman, SJ., Baskin, KM., Hodges, BL., Chu, Q., Gates, A., Dreusicke, R., Anderson, S. \& Scheule, R. (2002). Development of catheter-based procedures for transducing the isolated rabbit liver with plasmid DNA. Human gene therapy, 13(17), pp. 2065-77.

Ebersole, T., Ross, A., Clark, E., McGill, N., Schindelhauer, D., Cooke, H \& Grimes, B. (2000). Mammalian artificial chromosome formation from circular alphoid input DNA does not require telomere repeats. Human molecular genetics, 9(11), pp. 1623-31.

Ehrhardt, A., Engler, JA., Xu, H., Cherry, A., \& Kay, MA. (2006). Molecular analysis of chromosomal rearrangements in mammalian cells after phiC31-mediated integration. Human gene therapy, 17(11), pp. 1077-94.

Fischer, D., Bieber, T., Li, Y, Elsässer, H. P., \& Kissel, T. (1999). A novel non-viral vector for DNA delivery based on low molecular weight, branched polyethylenimine: effect of molecular weight on transfection efficiency and cytotoxicity. Pharmaceutical research, 16(8), pp. 1273-9.

Francastel, C., Walters, MC., Groudine, M., \& Martin, DI. (1999). A functional enhancer suppresses silencing of a transgene and prevents its localization close to centrometric heterochromatin. Cell, 99(3), pp. 259-69.

Gresch, O., Engel, F. B., Nesic, D., Tran, T., England, H., Hickman, E., Korner, I., Gan, L., Chen, S., Castro-Obregon, S., Hammermann, R., Wolf, J., Muler-Hartmann, H., Nix, M., Siebenkotten, G., Kraus, G. \& Lun, K. (2004). New non-viral method for gene transfer into primary cells. Methods, 33(2), pp. 151-63.

Griesenbach, U., \& Alton, EW. (2009). Cystic fibrosis gene therapy: successes, failures and hopes for the future. Expert review of respiratory medicine, 3(4), pp. 363-71.

Grimes, BR., Schindelhauer, D., McGill, NI., Ross, A., Ebersole, TA., \& Cooke, HJ. (2001). Stable gene expression from a mammalian artificial chromosome. EMBO reports, 2(10), pp. 910-4.

Groth, AC., \& Calos MP. (2004). Phage integrases: biology and applications. Journal of molecular biology, 335(3), pp. 667-78.

Haase, SB., \& Calos, MP. (1991). Replication control of autonomously replicating human sequences. Nucleic acids research, 19(18), pp. 5053-8.

Hacein-Bey-Abina, S, Von Kalle, C., Schmidt, M, McCormack, MP., Wulffraat, N, Leboulch, P., (2003). LMO2-associated clonal T cell proliferation in two patients after gene therapy for SCID-X1. Science, 302(5644), pp. 415-9.

Hacein-Bey-Abina, S., Von Kalle, C., Schmidt, M., Le Deist, F., Wulffraat, N., McIntyre, E., Radford, I., Villeval, JL., Fraser, C., Cabazzana-Calvo, M. \& Fischer, A. (2003). A serious adverse event after successful gene therapy for X-linked severe combined immunodeficiency. New England journal of medicine, 348(3), pp. 255-6.

Hagstrom, JE., Hegge, J., Zhang, G., Noble, M., Budker, V., Lewis, DL., Herweijer, H. \& Wolf, J. (2004). A facile nonviral method for delivering genes and siRNAs to skeletal muscle of mammalian limbs. Molecular therapy, 10(2), pp. 386-98.

Harrington, JJ., Van Bokkelen, G., Mays, RW., Gustashaw, K., \& Willard, HF. (1997). Formation of de novo centromeres and construction of first-generation human artificial microchromosomes. Nature genetics, 15(4), pp. 345-55. 
Harris, A, Young, BD., \& Griffin, BE. (1985). Random association of Epstein-Barr virus genomes with host cell metaphase chromosomes in Burkitt's lymphoma-derived cell lines. Journal of virology, 56(1), pp. 328-32.

Heaney, JD., Rettew, AN., \& Bronson, SK. (2004). Tissue-specific expression of a BAC transgene targeted to the Hprt locus in mouse embryonic stem cells. Genomics, 83(6), pp. 1072-82.

Heng, HQ., Goetze, S., Ye, CJ., Liu, G., Stevens, JB., Bremer, SW., Wykes, S., Bode, J. \& Krawetz, S. (2004). Chromatin loops are selectively anchored using scaffold/matrix-attachment regions. Journal of cell science, 117(Pt 7), pp. 999-1008.

Hibbitt, OC., Harbottle, RP., Waddington, SN., Bursill, CA., Coutelle, C., Channon, KM. \&Wade-Martins, R. (2007). Delivery and long-term expression of a $135 \mathrm{~kb}$ LDLR genomic DNA locus in vivo by hydrodynamic tail vein injection. Journal of gene medicine, 9(6), pp. 488-97.

Hodgson, JG., Smith, DJ., McCutcheon, K., Koide, HB., Nishiyama, K., Dinulos, MB., et al. (1996). Human huntingtin derived from YAC transgenes compensates for loss of murine huntingtin by rescue of the embryonic lethal phenotype. Human molecular genetics, 5(12), pp. 1875-85.

Huang, Y., Liu, DP., Wu, L., Li, TC., Wu, M., Feng, DX., et al. (2000). Proper developmental control of human globin genes reproduced by transgenic mice containing a $160-\mathrm{kb}$ BAC carrying the human beta-globin locus. Blood cells, molecules $\mathcal{E}$ diseases, 26(6), pp. 598-610.

Huertas, D., Howe, S, McGuigan, A., \& Huxley, C. (2000). Expression of the human CFTR gene from episomal oriP-EBNA1-YACs in mouse cells. Human molecular genetics, 9(4), pp. 617-29.

Hyde, S. C., Gill, D. R., Higgins, C. F., Trezise, A. E., MacVinish, L. J., Cuthbert, A. W., et al. (1993). Correction of the ion transport defect in cystic fibrosis transgenic mice by gene therapy. Nature, 362(6417), pp. 250-5.

Ivics, Z. \% Izsvak, S. (2010). The expanding universe of transposon technologies for gene and cell engineering. Mobile DNA, 1:25

Jackson, D. A., Juranek, S., \& Lipps, Hans J. (2006). Designing nonviral vectors for efficient gene transfer and long-term gene expression. Molecular therapy, 14(5), pp. 613-26.

Kakeda, M., Hiratsuka, M., Nagata, K., Kuroiwa, Y., Kakitani, M., Katoh, M., et al. (2005). Human artificial chromosome (HAC) vector provides long-term therapeutic transgene expression in normal human primary fibroblasts. Gene therapy, 12(10), pp. 852-6.

Keravala, A., Lee, S., Thyagarajan, Bhaskar, Olivares, Eric C, Gabrovsky, V. E., Woodard, L. E., et al. (2009). Mutational derivatives of PhiC31 integrase with increased efficiency and specificity. Molecular therapy, 17(1), pp. 112-20.

Koppel, I., Aid-Pavlidis, T., Jaanson, K., Sepp, M., Pruunsild, P., Palm, K., et al. (2009). Tissue-specific and neural activity-regulated expression of human BDNF gene in BAC transgenic mice. BMC neuroscience, 10, 68.

Kotin, R. M., Linden, R. M., \& Berns, K I. (1992). Characterization of a preferred site on human chromosome $19 \mathrm{q}$ for integration of adeno-associated virus DNA by nonhomologous recombination. EMBO journal, 11(13), pp. 5071-8.

Kotzamanis, G., Abdulrazzak, H., Gifford-Garner, J., Haussecker, PL., Cheung, W., GrillotCourvalin, C., et al. (2009). CFTR expression from a BAC carrying the complete 
human gene and associated regulatory elements. Journal of cellular and molecular medicine, 13(9A), pp. 2938-48.

Kotzamanis, George, Cheung, W., Abdulrazzak, H., Perez-Luz, S., Howe, Steven, Cooke, Howard, et al. (2005). Construction of human artificial chromosome vectors by recombineering. Gene, pp. 351, 29-38.

Kotzamanis, G., \& Huxley, C.. (2004). Recombining overlapping BACs into a single larger BAC. BMC biotechnology, $4,1$.

Laner, A., Goussard, S., Ramalho, A. S., Schwarz, T., Amaral, M. D., Courvalin, P., et al. (2005). Bacterial transfer of large functional genomic DNA into human cells. Gene therapy, 12(21), pp. 1559-72.

Larsen, M. D. B., Griesenbach, U, Goussard, S., Gruenert, D. C., Geddes, D M, Scheule, R K, et al. (2008). Bactofection of lung epithelial cells in vitro and in vivo using a genetically modified Escherichia coli. Gene therapy, 15(6), pp. 434-42.

Li, Q., Harju, S., \& Peterson, K. R. (1999). Locus control regions: coming of age at a decade plus. Trends in genetics : TIG, 15(10), 403-8.

Lipps, H J, Jenke, A. C. W., Nehlsen, K., Scinteie, M. F., Stehle, I M, \& Bode, J. (2003). Chromosome-based vectors for gene therapy. Gene, 304, pp. 23-33.

Liu, F., Song, Y., \& Liu, D. (1999). Hydrodynamics-based transfection in animals by systemic administration of plasmid DNA. Gene therapy, 6(7), pp. 1258-66.

Liu, Q., Perez, C. F., \& Wang, Yaming. (2006). Efficient site-specific integration of large transgenes by an enhanced herpes simplex virus/adeno-associated virus hybrid amplicon vector. Journal of virology, 80(4), pp. 1672-9.

Liu, R., Li, Yiming, Hu, R., Jin, T., Deng, S., Liang, W., et al. (2010). A site-specific genomic integration strategy for sustained expression of glucagon-like peptide-1 in mouse muscle for controlling energy homeostasis. Biochemical and biophysical research communications, 403(2), pp. 172-7.

Lufino, M. M. P., Manservigi, R., \& Wade-Martins, Richard. (2007). An S/MAR-based infectious episomal genomic DNA expression vector provides long-term regulated functional complementation of LDLR deficiency. Nucleic acids research, 35(15), e98.

Magin-Lachmann, C, Kotzamanis, G, D'Aiuto, L, Cooke, H, Huxley, C, \& Wagner, E. (2004). In vitro and in vivo delivery of intact BAC DNA -- comparison of different methods. Journal of gene medicine, 6(2), pp. 195-209.

Magin-Lachmann, C., Kotzamanis, G., D’Aiuto, L., Wagner, E., \& Huxley, C. (2003). Retrofitting BACs with G418 resistance, luciferase, and oriP and EBNA-1 - new vectors for in vitro and in vivo delivery. BMC biotechnology, 3(1), 2.

Manson, A. L., Trezise, A. E., MacVinish, L. J., Kasschau, K. D., Birchall, N., Episkopou, V., et al. (1997). Complementation of null CF mice with a human CFTR YAC transgene. EMBO journal, 16(14), pp. 4238-49.

Manzini, S., Vargiolu, A., Stehle, Isa M, Bacci, M. L., Cerrito, M. G., Giovannoni, R., et al. (2006). Genetically modified pigs produced with a nonviral episomal vector. Proceedings of the National Academy of Sciences USA, 103(47), pp. 17672-7.

Martin, D. I., \& Whitelaw, E. (1996). The vagaries of variegating transgenes. BioEssays, 18(11), pp. 919-23.

Maruyama, H., Higuchi, N., Nishikawa, Y., Hirahara, H., Iino, N., Kameda, S., et al. (2002). Kidney-targeted naked DNA transfer by retrograde renal vein injection in rats. Human gene therapy, 13(3), pp. 455-68.. 
Masucci, M. G., \& Ernberg, I. (1994). Epstein-Barr virus: adaptation to a life within the immune system. Trends in microbiology, 2(4), pp. 125-30.

McCarthy, V. A., \& Harris, Ann. (2005). The CFTR gene and regulation of its expression. Pediatric pulmonology, 40(1), pp. 1-8.

McCarty, D. M., Young, Samuel M, \& Samulski, R Jude. (2004). Integration of adenoassociated virus (AAV) and recombinant AAV vectors. Annual review of genetics, 38, pp. 819-45.

Mejía, J. E., \& Larin, Z. (2000). The assembly of large BACs by in vivo recombination. Genomics, 70(2), pp. 165-70.

Melman, A., Bar-Chama, N., McCullough, A., Davies, K., \& Christ, G. (2007). Plasmid-based gene transfer for treatment of erectile dysfunction and overactive bladder: results of a phase I trial. The Israel Medical Association journal, 9(3), pp. 143-6.

Meyer, K. B., Thompson, M. M., Levy, M. Y., Barron, L. G., \& Szoka, F. C. (1995). Intratracheal gene delivery to the mouse airway: characterization of plasmid DNA expression and pharmacokinetics. Gene therapy, 2(7), pp. 450-60.

Morishita, R., Makino, H., Aoki, M., Hashiya, N., Yamasaki, K., Azuma, J., et al. (2010). Phase I/IIa Clinical Trial of Therapeutic Angiogenesis Using Hepatocyte Growth Factor Gene Transfer to Treat Critical Limb Ischemia. Arteriosclerosis, thrombosis, and vascular biology.

Murisier, F., Guichard, S., \& Beermann, F. (2006). A conserved transcriptional enhancer that specifies Tyrp1 expression to melanocytes. Developmental biology, 298(2), pp. 644-55.

Muyrers, J. P., Zhang, Y., \& Stewart, A. F. (2001). Techniques: Recombinogenic engineering-new options for cloning and manipulating DNA. Trends in biochemical sciences, 26(5), pp. 325-31.

Oehmig, A, Cortés, M L, Perry, K F, Sena-Esteves, M., Fraefel, C., \& Breakefield, X O. (2007). Integration of active human beta-galactosidase gene $(100 \mathrm{~kb})$ into genome using HSV/AAV amplicon vector. Gene therapy, 14(14), pp. 1078-91.

Osoegawa, K., Mammoser, A. G., Wu, C., Frengen, E., Zeng, C., Catanese, J. J., et al. (2001). A bacterial artificial chromosome library for sequencing the complete human genome. Genome research, 11(3), pp. 483-96.

Papapetrou, E. P., Ziros, P. G., Micheva, I. D., Zoumbos, N. C., \& Athanassiadou, A. (2006). Gene transfer into human hematopoietic progenitor cells with an episomal vector carrying an S/MAR element. Gene therapy, 13(1), pp. 40-51.

Piechaczek, C., Fetzer, C., Baiker, A., Bode, J, \& Lipps, H J. (1999). A vector based on the SV40 origin of replication and chromosomal S/MARs replicates episomally in $\mathrm{CHO}$ cells. Nucleic acids research, 27(2), pp. 426-8.

Pérez-Luz, S., Abdulrazzak, H., Grillot-Courvalin, Catherine, \& Huxley, Clare. (2007). Factor VIII mRNA expression from a BAC carrying the intact locus made by homologous recombination. Genomics, 90(5), pp. 610-9.

Pérez-Luz, S., \& Díaz-Nido, J. (2010). Prospects for the use of artificial chromosomes and minichromosome-like episomes in gene therapy. Journal of biomedicine $\mathcal{E}$ biotechnology, 2010.

Quiñones, H. I., Savage, T. K., Battiste, J., \& Johnson, J. E. (2010). Neurogenin 1 (Neurog1) expression in the ventral neural tube is mediated by a distinct enhancer and preferentially marks ventral interneuron lineages. Developmental biology, 340(2), pp. 283-92. 
Raper, S. E., Chirmule, N., Lee, F. S., Wivel, N. A., Bagg, A., Gao, G.-ping, et al. (n.d.). Fatal systemic inflammatory response syndrome in a ornithine transcarbamylase deficient patient following adenoviral gene transfer. Molecular genetics and metabolism, 80(1-2), pp. 148-58.

Raviprakash, K., \& Porter, K. R. (2006). Needle-free injection of DNA vaccines: a brief overview and methodology. Methods in molecular medicine, 127, pp. 83-9.

Recchia, A., \& Mavilio, F. (2006). Site-specific integration into the human genome: ready for clinical application? Rejuvenation research, 9(4), pp. 446-9.

Riordan, J. R., Rommens, J. M., Kerem, B., Alon, N., Rozmahel, R., Grzelczak, Z., et al. (1989). Identification of the cystic fibrosis gene: cloning and characterization of complementary DNA. Science, 245(4922), pp. 1066-73.

Romero, N. B., Braun, S., Benveniste, O., Leturcq, F., Hogrel, J.-Y., Morris, G. E., et al. (2004). Phase I study of dystrophin plasmid-based gene therapy in Duchenne/Becker muscular dystrophy. Human gene therapy, 15(11), pp. 1065-76.

Rommens, J. M., Iannuzzi, M. C., Kerem, B., Drumm, M. L., Melmer, G., Dean, M., et al. (1989). Identification of the cystic fibrosis gene: chromosome walking and jumping. Science, 245(4922), pp. 1059-65.

Sarsero, J. P., Li, L., Holloway, T. P., Voullaire, Lucille, Gazeas, S., Fowler, K. J., et al. (2004). Human BAC-mediated rescue of the Friedreich ataxia knockout mutation in transgenic mice. Mammalian genome, 15(5), pp. 370-82.

Schedl, A., Montoliu, L., Kelsey, G., \& Schütz, G. (1993). A yeast artificial chromosome covering the tyrosinase gene confers copy number-dependent expression in transgenic mice. Nature, 362(6417), pp. 258-61.

Scherer, F., Anton, M., Schillinger, U., Henke, J., Bergemann, C., Krüger, A., et al. (2002). Magnetofection: enhancing and targeting gene delivery by magnetic force in vitro and in vivo. Gene therapy, 9(2), pp. 102-9.

Sclimenti, C. R., \& Calos, M P. (1998). Epstein-Barr virus vectors for gene expression and transfer. Current opinion in biotechnology, 9(5), pp. 476-9.

Shen, M. H., Yang, J. W., Yang, J., Pendon, C., \& Brown, W. R. (2001). The accuracy of segregation of human mini-chromosomes varies in different vertebrate cell lines, correlates with the extent of centromere formation and provides evidence for a trans-acting centromere maintenance activity. Chromosoma, 109(8), pp. 524-35.

Sheyn, D., Kimelman-Bleich, N., Pelled, G., Zilberman, Y., Gazit, D., \& Gazit, Z. (2008). Ultrasound-based nonviral gene delivery induces bone formation in vivo. Gene therapy, 15(4), pp. 257-66.

Smith, A. N., Wardle, C. J., \& Harris, A. (1995). Characterization of DNASE I hypersensitive sites in the $120 \mathrm{~kb} 5^{\prime}$ to the CFTR gene. Biochemical and biophysical research communications, 211(1), pp. 274-81.

Song, Y. K., Liu, F., Chu, S., \& Liu, D. (1997). Characterization of cationic liposome-mediated gene transfer in vivo by intravenous administration. Human gene therapy, 8(13), pp. 1585-94.

Srivastava, A., Lusby, E. W., \& Berns, K I. (1983). Nucleotide sequence and organization of the adeno-associated virus 2 genome. Journal of virology, 45(2), pp. 555-64.

Takahashi, K., Tanabe, K., Ohnuki, M., Narita, M., Ichisaka, T., Tomoda, K., et al. (2007). Induction of pluripotent stem cells from adult human fibroblasts by defined factors. Cell, 131(5), pp. 861-72. 
Thyagarajan, Bhaskar, Liu, Y., Shin, S., Lakshmipathy, U., Scheyhing, K., Xue, H., et al. (2008). Creation of engineered human embryonic stem cell lines using phiC31 integrase. Stem cells, 26(1), pp. 119-26.

Tischer, B. K., Schumacher, D., Beer, M., Beyer, J., Teifke, J. P., Osterrieder, K., et al. (2002). A DNA vaccine containing an infectious Marek's disease virus genome can confer protection against tumorigenic Marek's disease in chickens. Journal of general virology, 83(Pt 10), pp. 2367-76.

Tong, J., Lillico, S. G., Bi, M. J., Qing, T., Liu, X. F., Wang, Yuanyuan, et al. (2010). Tissuespecific and expression of porcine growth hormone gene in BAC transgenic mice. Transgenic research.

Tros de Ilarduya, C., Sun, Y., \& Düzgüneş, N. (2010). Gene delivery by lipoplexes and polyplexes. European journal of pharmaceutical sciences, 40(3), pp. 159-70.

Venken, K. J. T., He, Y., Hoskins, R. A., \& Bellen, H. J. (2006). P[acman]: a BAC transgenic platform for targeted insertion of large DNA fragments in D. melanogaster. Science, N.Y.), 314(5806), pp. 1747-51.

Verma, I. M., \& Weitzman, M. D. (2005). Gene therapy: twenty-first century medicine. Annual review of biochemistry, 74, pp. 711-38.

Voet, T., Vermeesch, J., Carens, A., Dürr, J., Labaere, C., Duhamel, H., et al. (2001). Efficient male and female germline transmission of a human chromosomal vector in mice. Genome research, 11(1), pp. 124-36.

Voigt, K., Izsvák, Z., \& Ivics, Z. (2008). Targeted gene insertion for molecular medicine. Journal of molecular medicine, 86(11), pp. 1205-19. .

Wade-Martins, R, White, R. E., Kimura, H., Cook, P. R., \& James, M. R. (2000). Stable correction of a genetic deficiency in human cells by an episome carrying a $115 \mathrm{~kb}$ genomic transgene. Nature biotechnology, 18(12), pp. 1311-4.

Wade-Martins, R., Saeki, Y., \& Chiocca, E. A. (2003). Infectious delivery of a 135-kb LDLR genomic locus leads to regulated complementation of low-density lipoprotein receptor deficiency in human cells. Molecular therapy, 7(5 Pt 1), pp. 604-12.

Walther, W., Siegel, R., Kobelt, D., Knösel, T., Dietel, M., Bembenek, A., et al. (2008). Novel jet-injection technology for nonviral intratumoral gene transfer in patients with melanoma and breast cancer. Clinical cancer research, 14(22), pp. 7545-53.

Wang, G., Bunnell, B. A., Painter, R. G., Quiniones, B. C., Tom, S., Lanson, N. A., et al. (2005). Adult stem cells from bone marrow stroma differentiate into airway epithelial cells: potential therapy for cystic fibrosis. Proceedings of the National Academy of Sciences USA, 102(1), pp. 186-91.

Wells, D J. (2004). Gene therapy progress and prospects: electroporation and other physical methods. Gene therapy, 11(18), pp. 1363-9.

Wolff, J A, Malone, R. W., Williams, P., Chong, W., Acsadi, G., Jani, A., et al. (1990). Direct gene transfer into mouse muscle in vivo. Science, 247(4949 Pt 1), pp. 1465-8.

Xenariou, S, Griesenbach, U, Ferrari, S., Dean, P., Scheule, R K, Cheng, S H, et al. (2006). Using magnetic forces to enhance non-viral gene transfer to airway epithelium in vivo. Gene therapy, 13(21), pp. 1545-52.

Xenariou, Stefania, Liang, H.-D., Griesenbach, Uta, Zhu, J., Farley, Raymond, Somerton, L., et al. (2010). Low-frequency ultrasound increases non-viral gene transfer to the mouse lung. Acta biochimica et biophysica Sinica, 42(1), pp. 45-51. 
Xing, L., Salas, M., Lin, C.-S., Zigman, W., Silverman, W., Subramaniyam, S., et al. (2007). Faithful tissue-specific expression of the human chromosome 21-linked COL6A1 gene in BAC-transgenic mice. Mammalian genome, 18(2), pp. 113-22.

Yamashita, Y.-ichi, Shimada, M., Tachibana, K., Harimoto, N., Tsujita, E., Shirabe, K., et al. (2002). In vivo gene transfer into muscle via electro-sonoporation. Human gene therapy, 13(17), pp. 2079-84.

Yang, N. S., Burkholder, J., Roberts, B., Martinell, B., \& McCabe, D. (1990). In vivo and in vitro gene transfer to mammalian somatic cells by particle bombardment. Proceedings of the National Academy of Sciences USA, 87(24), pp. 9568-72.

Yates, J. L., Warren, N., \& Sugden, B. (1985.). Stable replication of plasmids derived from Epstein-Barr virus in various mammalian cells. Nature, 313(6005), pp. 812-5.

Yu, J., Vodyanik, M. A., Smuga-Otto, K., Antosiewicz-Bourget, J., Frane, J. L., Tian, S., et al. (2007). Induced pluripotent stem cell lines derived from human somatic cells. Science, 318(5858), pp. 1917-20.

Zeira, E., Manevitch, A., Khatchatouriants, A., Pappo, O., Hyam, E., Darash-Yahana, M., et al. (2003). Femtosecond infrared laser-an efficient and safe in vivo gene delivery system for prolonged expression. Molecular therapy, 8(2), pp. 342-50.

Zhang, G., Budker, V., \& Wolff, JA. (1999). High levels of foreign gene expression in hepatocytes after tail vein injections of naked plasmid DNA. Human gene therapy, 10(10), pp. 1735-7.

Zhang, XM., \& Huang, JD. (2003). Combination of overlapping bacterial artificial chromosomes by a two-step recombinogenic engineering method. Nucleic acids research, 31(15), e81. 


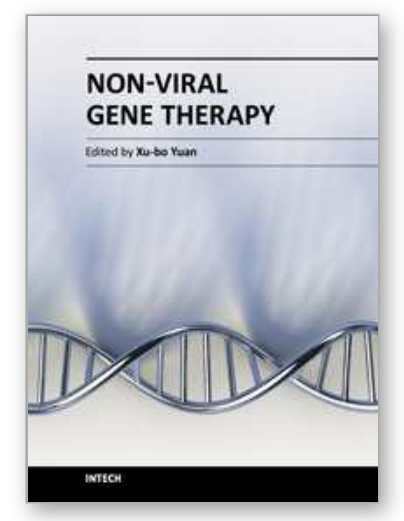

\author{
Non-Viral Gene Therapy \\ Edited by Prof. Xubo Yuan
}

ISBN 978-953-307-538-9

Hard cover, 696 pages

Publisher InTech

Published online 07, November, 2011

Published in print edition November, 2011

This book focuses on recent advancement of gene delivery systems research. With the multidisciplinary contribution in gene delivery, the book covers several aspects in the gene therapy development: various gene delivery systems, methods to enhance delivery, materials with modification and multifunction for the tumor or tissue targeting. This book will help molecular biologists gain a basic knowledge of gene delivery vehicles, while drug delivery scientist will better understand DNA, molecular biology, and DNA manipulation.

\title{
How to reference
}

In order to correctly reference this scholarly work, feel free to copy and paste the following:

George Kotzamanis, Hassan Abdulrazzak, Athanassios Kotsinas and Vassilis G. Gorgoulis (2011). Non-Viral Gene Therapy Vectors Carrying Genomic Constructs, Non-Viral Gene Therapy, Prof. Xubo Yuan (Ed.), ISBN: 978-953-307-538-9, InTech, Available from: http://www.intechopen.com/books/non-viral-gene-therapy/nonviral-gene-therapy-vectors-carrying-genomic-constructs

\section{INTECH}

open science | open minds

\author{
InTech Europe \\ University Campus STeP Ri \\ Slavka Krautzeka 83/A \\ 51000 Rijeka, Croatia \\ Phone: +385 (51) 770447 \\ Fax: +385 (51) 686166 \\ www.intechopen.com
}

\author{
InTech China \\ Unit 405, Office Block, Hotel Equatorial Shanghai \\ No.65, Yan An Road (West), Shanghai, 200040, China \\ 中国上海市延安西路65号上海国际贵都大饭店办公楼 405 单元 \\ Phone: +86-21-62489820 \\ Fax: $+86-21-62489821$
}


(C) 2011 The Author(s). Licensee IntechOpen. This is an open access article distributed under the terms of the Creative Commons Attribution 3.0 License, which permits unrestricted use, distribution, and reproduction in any medium, provided the original work is properly cited. 